\title{
MOLECULAR STRUCTURE OF THALLIUM(III) MESO-TETRAPHENYLPORPHYRIN ACETATE: Tl(tpp)(OAc)
}

\author{
SHIN-CHU SUEN, WEN-BIN LEE, FUNG-E HONG, TING-TING JONG \\ and JYH-HORUNG CHEN $\dagger$
}

Department of Chemistry, National Chunghsing University, Taichung 40227, Taiwan, R.O.C.

and

\section{LIAN-PIN HWANG}

Department of Chemistry, National Taiwan University and Institute of Atomic and Molecular Sciences, Academia Sinica, Taipei 10764, Taiwan, R.O.C.

(Received 30 June 1992; accepted 10 August 1992)

\begin{abstract}
X-ray diffraction data and solid-state ${ }^{13} \mathrm{C} \mathrm{CP} / \mathrm{MAS}$ spectra of thallium(III) mesotetraphenylporphyrin acetate, $\mathrm{Tl}(\mathrm{tpp})(\mathrm{OAc})$, provide evidence for a chelating-bidentate acetato group coordinated to the thallium(III) atom. The displacement of the thallium atom from the porphyrin mean plane was $0.842 \AA$. The geometry around the thallium centre of the $T l(t p p)(O A c)$ molecule has $\mathrm{Tl}-\mathrm{O}(1)=2.361(9), \mathrm{Tl}-\mathrm{O}(2)=2.229(10)$ and $\mathrm{Tl}-\mathrm{N}=2.219(7) \AA$. Fourier-transform IR spectra $\left(400-4000 \mathrm{~cm}^{-1}\right)$ of $\mathrm{Tl}(\mathrm{tpp})(\mathrm{OAc})$ in $\mathrm{KBr}$ discs and in $\mathrm{CH}_{2} \mathrm{Cl}_{2}$ solvent are reported and assigned by comparison with the spectra of $\mathrm{Tl}(\mathrm{tpp})(\mathrm{CN})$. It is concluded that the intramolecular exchange of the acetato group between asymmetric pseudo-chelating $\mathbf{c}$ and $\mathbf{d}$ result in the adaptation of the chelating bidentate, a for the carboxylate at low temperature and that of the symmetric pseudochelating $b$ at high temperature for $\mathrm{Tl}(\mathrm{tpp})(\mathrm{OAc})$ in $\mathrm{CH}_{2} \mathrm{Cl}_{2}$ solvent. This explains the resonances of ${ }^{13} \mathrm{C}$ and ${ }^{1} \mathrm{H}$ of the axial acetato group in low- and high-temperature solution NMR measurements.
\end{abstract}

Carboxylates serve as an important class of ligands in inorganic chemistry. In mononuclear complexes the carboxylate ion may coordinate to a metal in one of the following modes:
The most common forms are unidentate (I), chelating-bidentate (II), free carboxylate (IV) and asymmetric pseudo-chelating (III). ${ }^{1-3}$

In a previous paper, ${ }^{4}$ we reported the dynamic<smiles>[M]OC([R])=O</smiles>

anti monodentate terminal

(Ia)<smiles>[M]OC([R])=O</smiles>

syn monodentate terminal

(Ib)<smiles></smiles>

chelating-bidentate (II)<smiles>[R]c1[M]2oc1o2</smiles>

asymmetric (pseudo-chelating)

(III)<smiles>[R]C(=O)C(=O)O[Na]</smiles>

free carboxylate

(IV)

† Author to whom correspondence should be addressed. 
NMR studies on the thallium(III) meso-tetraphenylporphyrin acetate $\mathrm{Tl}(\mathrm{tpp})(\mathrm{OAc})$. It was found that the intermolecular exchange of the acetato group had an activation energy of $4.1 \mathrm{kcal}$ $\mathrm{mol}^{-1}$ in $\mathrm{CD}_{2} \mathrm{Cl}_{2}$. However, some ambiguities remain, because it is difficult to break two $\mathrm{Tl}-\mathrm{O}$ bonds to undergo the intermolecular exchange with such a low activation energy. Due to the ring current effect, the ' $\mathrm{H}$ chemical shifts of the axial acetato proton of $\mathrm{Tl}(\mathrm{tpp})(\mathrm{OAc})$ in $\mathrm{CD}_{2} \mathrm{Cl}_{2}$ at $24^{\circ} \mathrm{C}$ are shifted upfield $c a 2.04 \mathrm{ppm}$ from 2.1 (obtained on the acetic acid) to $0.06 \mathrm{ppm}$. The observation that the methyl protons of the apical acetate ligand appear as a sharp singlet at $\delta=0.06 \mathrm{ppm}$ was an indication that the acetate ligand still remained in the axial position of the complex, even though the axial acetate exchange was a fast process compared with ${ }^{4} J(\mathrm{Tl}-\mathrm{H})=14.7 \mathrm{~Hz}$ at $24^{\circ} \mathrm{C}$. There is some argument about the validity of using intermolecular exchange to explain the NMR observation in the previous paper. ${ }^{4}$ In order to elucidate the exchange mechanism, we now report the molecular structure of the crystalline $\mathrm{Tl}(\mathrm{tpp})(\mathrm{OAc})$ by X-ray analysis. On the NMR time-scale the X-ray structure of the solid at room temperature is a good simulation for the structure in solution at low temperature. The comparison of the Fourier transform spectra of $\mathrm{Tl}(\mathrm{tpp})(\mathrm{OAc})$ in crystals, expressed by $\mathrm{Tl}(\mathrm{tpp})$ (OAc)-S, and in $\mathrm{CH}_{2} \mathrm{Cl}_{2}$, cxpressed by $\mathrm{Tl}(\mathrm{tpp})$ (OAc) $-\mathrm{L}$, will disclose that the intramolecular acetate exchange is the chief exchange mechanism.

\section{EXPERIMENTAL}

\section{Crystal data}

$\mathrm{C}_{46} \mathrm{H}_{31} \mathrm{~N}_{4} \mathrm{O}_{2} \mathrm{Tl}, M=876.1$, monoclinic, space group $P 2_{1} / n, a=10.276(2), b=16.610(4), c=$ $21.148(6) \AA, \gamma=90.86(2)^{\circ}, V=3609.2(1) \AA^{3}, D_{\mathrm{c}}=$ $1.612 \mathrm{~g} \mathrm{~cm}^{-3}, \mu=45.63 \mathrm{~cm}^{-1}, F(000)=1728$, $Z=4$ formula units/unit cell. Intensities were collected for a crystal of dimensions $0.2 \times 0.4 \times 0.5 \mathrm{~mm}$ on a Siemens $\mathrm{R} 3 \mathrm{~m} / \mathrm{V}$ diffractometer using monochromatized Mo- $K_{\alpha}$ radiation $(\lambda=0.7107 \AA)$, via the $\theta-2 \theta$ scan technique. The structure was solved by direct methods (see Table 1 for important crystal information and details on data collection). All the non-hydrogen atoms were defined with anisotropic thermal parameters, whereas all hydrogen atoms were refined isotropically and included in the structure factor calculation. The final agreement factors were $R=0.056$ and $R_{\mathrm{w}}=0.0597$ for 478 variables and 5113 unique reflections with $I>3 \sigma(I)$. The GOF was 1.32. A selection of bond distances and angles is given in Table 2 .
Table 1. Crystal data

\begin{tabular}{ll}
\hline Formula & $\mathrm{C}_{46} \mathrm{H}_{31} \mathrm{~N}_{4} \mathrm{O}_{2} \mathrm{~T} 1$ \\
Formula weight & 876.1 \\
$a(\AA)$ & $10.276(2)$ \\
$b(\AA)$ & $16.610(4)$ \\
$c(\AA)$ & $21.148(6)$ \\
$\gamma\left({ }^{\circ}\right)$ & $90.86(2)$ \\
$V\left(\AA^{3}\right)$ & $3609.2(1)$ \\
$Z$ & 4 \\
$D_{\mathrm{c}}\left(\mathrm{g} \mathrm{cm}^{-3}\right)$ & 1.612 \\
Space group & $P 2, / n$ \\
$F(000)$ & 1728 \\
$\mu\left(\mathrm{cm}{ }^{-1}\right)$ & 45.63 \\
$R^{a}(\%)$ & 5.6 \\
$R_{\mathrm{w}}{ }^{2}(\%)$ & 5.97 \\
GOF & 1.32 \\
$A^{b}$ & 1 \\
$B^{h}$ & $1.0 \times 10^{-3}$ \\
Crystal size (mm) & $0.2 \times 0.4 \times 0.5$ \\
Data collected & 11,379 \\
$2 \theta_{\text {max }}\left({ }^{\circ}\right)$ & 60 \\
Temperature $(\mathrm{K})$ & 293 \\
Data used & 5113 \\
Discrimination & $I>3 \sigma(I)$ \\
\hline
\end{tabular}

$$
\begin{aligned}
& { }^{a} R=\left[\Sigma|| F_{\mathrm{o}}|-| F_{\mathrm{c}}|/| F_{\mathrm{o}} \mid\right] . \\
& { }^{b} R_{\mathrm{w}}=\left[\left(\Sigma \mathrm{w}\left(\left\|F_{\mathrm{o}}|-| F_{\mathrm{c}}\right\|^{2} / \Sigma \mathrm{w}\left|F_{\mathrm{o}}\right|^{2}\right)^{1 / 2}\right] ;\right. \\
& \mathrm{w}=A /\left(\sigma^{2} F_{\mathrm{o}}+B F_{\mathrm{o}}{ }^{2}\right) .
\end{aligned}
$$

\section{Preparation of the complex}

This complex was prepared as previously reported $^{5}$ and crystals were grown by the diffusion of $\mathrm{CH}_{2} \mathrm{Cl}_{2}$ vapour into a toluene solution.

\section{NMR spectra}

$\mathrm{CP} / \mathrm{MAS}{ }^{13} \mathrm{C}$ solid-state NMR spectra were recorded at $26^{\circ} \mathrm{C}$ at $50.33 \mathrm{MHz}$ using a Bruker MSL 200 solid-state NMR spectrometer.

\section{IR spectra}

IR spectra were recorded both in $\mathrm{KBr}$ discs and in $\mathrm{CH}_{2} \mathrm{Cl}_{2}$ solvent on BOMEM MB-100 and BOMEM DA-3.002 Fourier transform IR spectrometers.

\section{RESULTS AND DISCUSSION}

\section{Description of the structure}

The skeletal framework of the Tl(tpp)(OAc) molecule is illustrated in Fig. 1. It reveals the six-coordination of the thallium atom with four nitrogen atoms $(\mathrm{Np})$ of the porphyrinato group and the chel- 
Table 2. Selection of bond distances $(\AA)$ and angles ( $\left.{ }^{\circ}\right)$

\begin{tabular}{|c|c|c|c|}
\hline $\mathrm{Tl}(1)-\mathrm{O}(1)$ & $2.361(9)$ & $\mathrm{Tl}(1)-\mathrm{N}(4)$ & $2.214(7)$ \\
\hline $\mathrm{Tl}(1)-\mathrm{O}(2)$ & $2.299(10)$ & $\mathrm{O}(1)-\mathrm{C}(1)$ & $1.180(14)$ \\
\hline $\mathrm{Tl}(1)-\mathrm{N}(1)$ & $2.204(7)$ & $O(2)-C(1)$ & $1.187(14)$ \\
\hline $\mathrm{Tl}(1)-\mathrm{N}(2)$ & $2.237(7)$ & $C(1)-C(1 a)$ & $1.508(15)$ \\
\hline $\mathrm{Tl}(1)-\mathrm{N}(3)$ & $2.222(7)$ & & \\
\hline$O(1)-\mathrm{Tl}(1)-\mathrm{O}(2)$ & $51.6(4)$ & $\mathrm{O}(1)-\mathrm{Tl}(1)-\mathrm{N}(4)$ & $90.7(3)$ \\
\hline$O(1)-T 1(1)-N(1)$ & $90.2(3)$ & $\mathrm{O}(2)-\mathrm{Tl}(1)-\mathrm{N}(4)$ & $130.2(3)$ \\
\hline $\mathrm{O}(2)-\mathrm{T} 1(1)-\mathrm{N}(1)$ & $121.5(3)$ & $\mathrm{N}(1)-\mathrm{Tl}(1)-\mathrm{N}(4)$ & $83.9(2)$ \\
\hline $\mathrm{O}(1)-\mathrm{T} 1(1)-\mathrm{N}(2)$ & $127.5(3)$ & $\mathrm{N}(2)-\mathrm{Tl}(1)-\mathrm{N}(4)$ & $139.4(3)$ \\
\hline $\mathrm{O}(2)-\mathrm{Tl}(1)-\mathrm{N}(2)$ & $88.8(3)$ & $\mathrm{N}(3)-\mathrm{Tl}(1)-\mathrm{N}(4)$ & $82.6(3)$ \\
\hline$N(1)-T(1)-N(2)$ & $83.1(2)$ & $\mathrm{Tl}(1)-\mathrm{O}(1)-\mathrm{C}(1)$ & $93.6(7)$ \\
\hline $\mathrm{O}(1)-\mathrm{T} 1(1)-\mathrm{N}(3)$ & $127.3(3)$ & $\mathrm{Tl}(1)-\mathrm{O}(2)-\mathrm{C}(1)$ & $96.6(7)$ \\
\hline $\mathrm{O}(2)-\mathrm{Tl}(1)-\mathrm{N}(3)$ & $95.5(3)$ & $O(1)-C(1)-O(2)$ & $118.1(10)$ \\
\hline$N(1)-T l(1)-N(3)$ & $140.1(2)$ & $O(1)-C(1)-C(1 a)$ & $122.4(9)$ \\
\hline$N(2)-T(1)-N(3)$ & $83.2(2)$ & $O(2)-C(1)-C(1 a)$ & $119.5(10)$ \\
\hline
\end{tabular}

ating bidentate $\mathrm{COO}^{-}$; the coordination polyhedra were: $\mathrm{Tl}(1)-\mathrm{O}(1)=2.361, \mathrm{Tl}(1)-\mathrm{O}(2)=2.299$, $\mathrm{O}(1)-\mathrm{C}(1)=1.180, \mathrm{O}(2)-\mathrm{C}(1)=1.187 \AA$ and the mean $\mathrm{Tl}(1)-\mathrm{Np}=2.219 \AA$. The thallium(I) atom lies $0.842 \AA$ above the plane defined by the porphyrin ring system, and the $\mathrm{O}(1)-\mathrm{Tl}(1)-\mathrm{O}(2)$ bond angle is $51.6^{\circ}$. The dihedral angles between the mean plane of the porphine skeleton and the planes of the four phenyl groups are 70.0,65.6,86.3 and $78.3^{\circ}$, respectively. According to the $\mathrm{X}$-ray analysis, the structure of $\mathrm{Tl}(\mathrm{tpp})(\mathrm{OAc})-\mathrm{S}$ has type II acetate coordinations.

\section{Solid-state NMR spectroscopy}

Solid-state ${ }^{13} \mathrm{C} \mathrm{CP} / \mathrm{MAS}$ data of crystalline $\mathrm{Tl}(\mathrm{tpp})(\mathrm{OAc})$ at $26^{\circ} \mathrm{C}$ are shown in Table 3, with

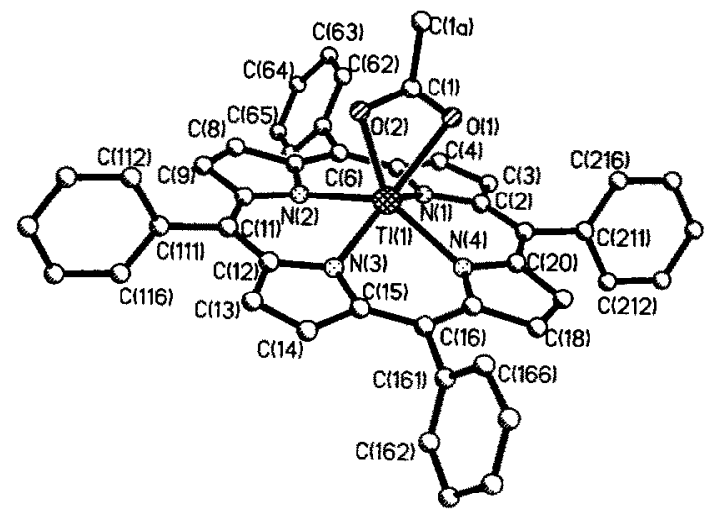

Fig. 1. Molecular configuration and labelling scheme of atoms (hydrogen atoms omitted) in Tl(tpp)(OAc). relevant literature values. Three major resonances with the methyl carbon at $\delta=18.5$, carboxyl carbon at $\delta=173.1$ and meso-carbons at $\delta=122.8$ ppm were observed. Both the ${ }^{13} \mathrm{C}$ chemical shift and thallium-carbon coupling constant data for the crystalline are consistent with the low-temperature solution data of $\mathrm{Tl}(\mathrm{tpp})(\mathrm{OAc})$ in $\mathrm{CD}_{2} \mathrm{Cl}_{2}$ at $-90^{\circ} \mathrm{C}$. This provides further evidence that the carboxylate is chelating the thallium atom in the crystalline state. The structure of Tl(tpp)(OAc)-L at low temperature might be as in structure $\mathbf{I}$.

\section{IR spectroscopy}

IR spectra of Tl(tpp)(OAc)-S and Tl(tpp)(OAc)$L$ are displayed in Figs 2(a) and (b), respectively. The IR spectrum of meso-tetraphenylporphyrinato

Table 3. Comparison of ${ }^{13} \mathrm{C}$ shifts $(\delta)$ and thalliumcarbon coupling constant $(J)$ in $\mathrm{Hz}$ of $\mathrm{Tl}(\mathrm{tpp})(\mathrm{OAc})$ between solution and solid-state NMR measurements ${ }^{a}$

\begin{tabular}{cccc}
\hline Temperature $\left({ }^{\circ} \mathrm{C}\right)$ & $\mathrm{C}_{\text {meso }}$ & $\mathrm{COC}^{*} \mathrm{H}_{3}$ & $\mathrm{C}^{*} \mathrm{OCH}_{3}$ \\
\hline $26^{b}$ & 122.8 & 18.5 & 173.1 \\
& $(147)$ & $(318)$ & $(263)$ \\
$-90^{c}$ & 122.5 & 18.8 & 174.9 \\
& $(148)$ & $(280)$ & $(235)$
\end{tabular}

${ }^{a}$ Chemical shifts in ppm relative to TMS. Values in parentheses are $J\left(\mathrm{Tl}-{ }^{13} \mathrm{C}\right)$ coupling constants in $\mathrm{Hz}$.

${ }^{b} \mathrm{CP} / \mathrm{MAS}{ }^{13} \mathrm{C}$ solid-state NMR measurements.

'Solution NMR in $\mathrm{CD}_{2} \mathrm{Cl}_{2}$ from Ref. 4. 

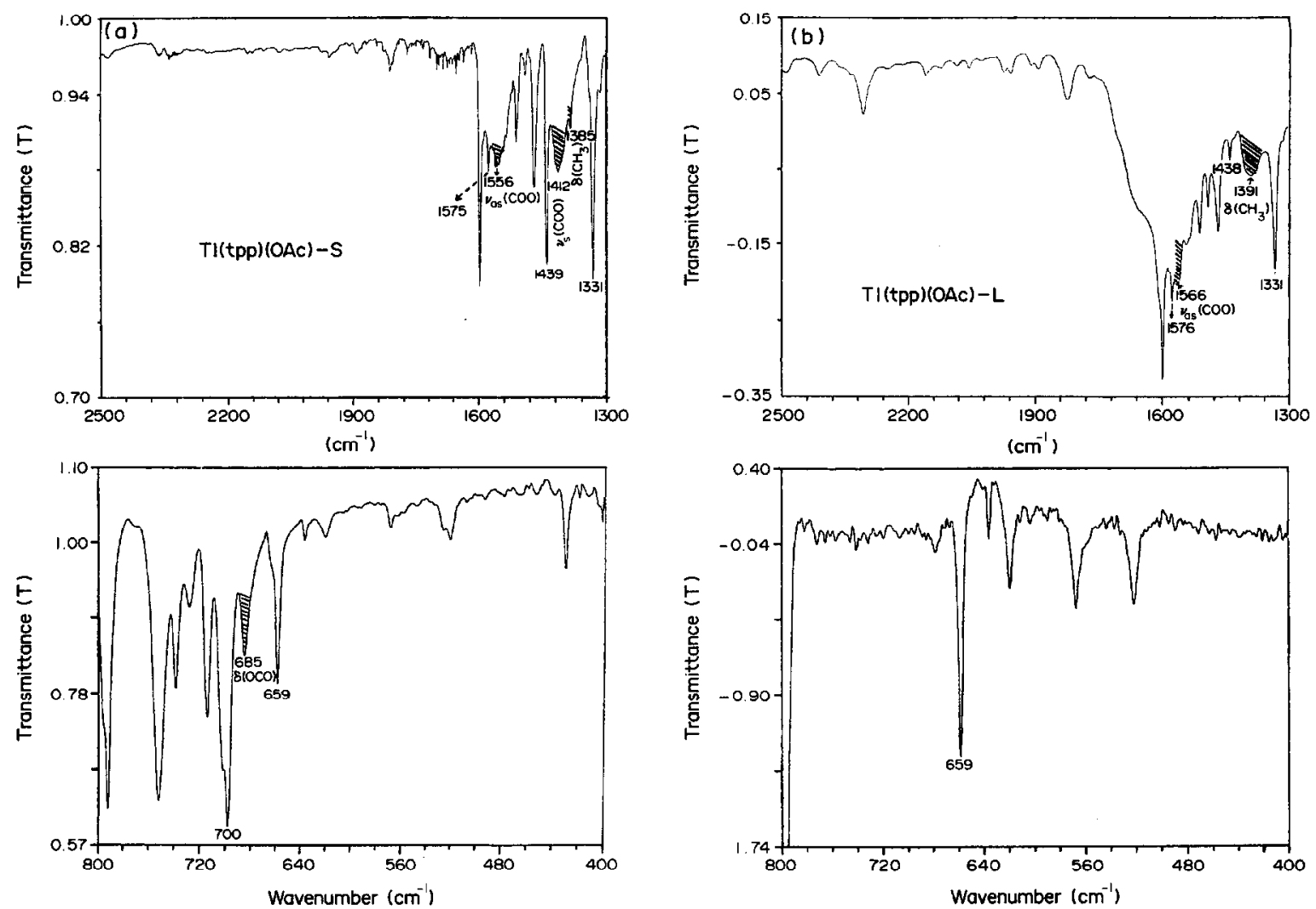

Fig. 2. IR spectra of (a) solid $\mathrm{Tl}(\mathrm{tpp})(\mathrm{OAc})$ and (b) $\mathrm{Tl}(\mathrm{tpp})(\mathrm{OAc})$ in $\mathrm{CH}_{2} \mathrm{Cl}_{2}$. Both spectra were recorded at $24^{\circ} \mathrm{C}$. The hatched bands were assigned to the vibrations of the coordinated acetate molecules.

thallium(III) cyanide, ${ }^{6} \mathrm{Tl}(\mathrm{tpp})(\mathrm{CN})$, is shown in Fig. 3. A comparison of the vibrational frequencies of $\mathrm{Tl}(\mathrm{tpp})(\mathrm{OAc})-\mathrm{S}$ [shown in Fig. 2(a)] with those of Tl(tpp)(CN) (shown in Fig. 3) enable assignment of the bands at $1556\left[v_{\mathrm{asym}}\left(\mathrm{CO}_{2}\right)\right], 1412\left[v_{\mathrm{sym}}\left(\mathrm{CO}_{2}\right)\right]$,
$1385\left[\delta\left(\mathrm{CH}_{3}\right), \mathrm{CH}_{3}\right.$ symmetric deformation] and $685 \mathrm{~cm}^{-1}$ [ $\delta(\mathrm{OCO})$, symmetric $\mathrm{O}-\mathrm{C}-\mathrm{O}$ deformation] as due to the chelating-bidentate acetates in Tl(tpp)(OAc)-S. On the basis of comparisons with the IR spectra of Tl(tpp)(OAc)-S [shown in

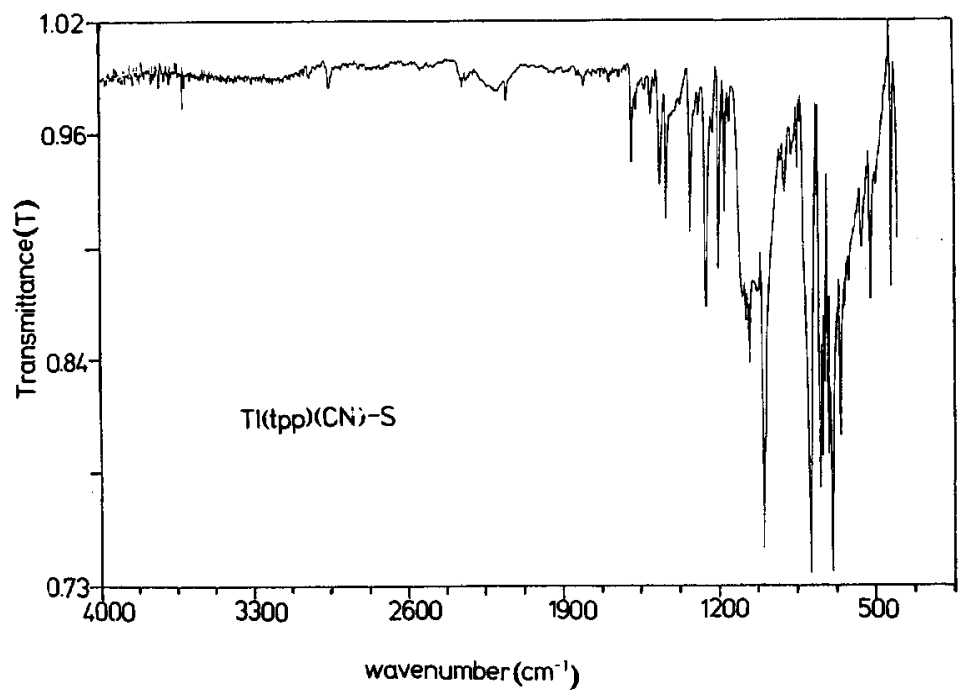

Fig. 3. IR spectrum of solid $\mathrm{Tl}(\mathrm{tpp})(\mathrm{CN})$ at $24^{\circ} \mathrm{C}$. 
Table 4. Selected IR frequencies and band assignment for acetate ions $\left(\mathrm{cm}^{-1}\right)$ and $\mathrm{Tl}(\mathrm{tpp})(\mathrm{OAc})$ in the crystalline state $\left(\mathrm{cm}^{-1}\right)$ and in liquid $\mathrm{CH}_{2} \mathrm{Cl}_{2}$

\begin{tabular}{ccccc}
\hline $\begin{array}{c}\text { Band } \\
\text { assignment }\end{array}$ & $\begin{array}{c}\mathrm{CH}_{3} \mathrm{COO}^{-7} \\
\text { solid }\end{array}$ & $\begin{array}{c}\mathrm{CH}_{3} \mathrm{COO}^{-7} \\
\text { aqueous } \\
\text { solution }\end{array}$ & $\begin{array}{c}\mathrm{Tl}(\mathrm{tpp})(\mathrm{OAc})-\mathrm{S}^{a} \\
\text { (chelating, } \\
\text { bidentate) }\end{array}$ & $\begin{array}{c}\mathrm{Tl}(\mathrm{tpp})(\mathrm{OAc})-\mathrm{L}^{a} \\
\text { (pseudo-chelating) }\end{array}$ \\
\hline$v_{\text {as }}(\mathrm{COO})$ & 1578 & 1556 & 1556 & 1566 \\
$v_{\mathrm{s}}(\mathrm{COO})$ & 1414 & 1413 & 1412 & - \\
$\delta\left(\mathrm{CH}_{3}\right)$ & 1430 & 1344 & 1385 & 1391 \\
$\delta(\mathrm{OCO})$ & 646 & 650 & 685 & - \\
$\rho_{\mathrm{r}}(\mathrm{COO})$ & 460 & 471 & - & - \\
\hline
\end{tabular}

${ }^{a} \mathrm{~S}=$ solid and $\mathrm{L}=$ liquid in $\mathrm{CH}_{2} \mathrm{Cl}_{2}$. Both data are recorded at $24^{\circ} \mathrm{C}$.

Fig. 2(a)], the bands at $1566\left[v_{\text {asym }}\left(\mathrm{CO}_{2}\right)\right]$ and 1391 $\mathrm{cm}^{-1}\left[\delta\left(\mathrm{CH}_{3}\right)\right]$ shown in Fig. 2(b) have been assigned to modes of vibrational frequencies due to the asymmetric pseudo-chelating acetate in $\mathrm{Tl}(\mathrm{tpp})(\mathrm{OAc})-\mathrm{L}$. Bond frequencies and assignments of the coordinated acetate molecules are listed in Table 4. On going from $\mathrm{Tl}(\mathrm{tpp})(\mathrm{OAc})-\mathrm{S}$ to $\mathrm{Tl}(\mathrm{tpp})(\mathrm{OAc})-\mathrm{L}$ at $24^{\circ} \mathrm{C}$, bands of $v_{\mathrm{s}}\left(\mathrm{CO}_{2}\right)$ and $\delta(\mathrm{COC})$, which are symmetric modes of $\mathrm{COO}$, disappear and only the antisymmetric $\mathrm{CO}_{2}$ stretching mode at $1566 \mathrm{~cm}^{-1}$ exists.

If the intermolecular acetato exchange (shown in Scheme I) proceeds in $\mathrm{Tl}(\mathrm{tpp})(\mathrm{OAc})-\mathrm{L}$, we should see the "free" $\mathrm{CH}_{3} \mathrm{COO}^{-}$ion, with structure IV, at $24^{\circ} \mathrm{C}$. This ion has symmetric and antisymmetric COO stretching modes at 1415 and $1570 \mathrm{~cm}^{-1}$. It has been examined in solution and in the solid state of sodium acetate by Ito and Bernstein, ${ }^{7}$ which is also depicted in Table 4. The IR data of $\mathrm{Tl}(\mathrm{tpp})(\mathrm{OAc})-\mathrm{L}$ at $24^{\circ} \mathrm{C}$ were different from those of free acetate, as shown in Table 4. Second, instead of observing the proton resonance of methyl at $2.1 \mathrm{ppm}$, it was observed at $0.06 \mathrm{pm}$. Both results indicate that structure IV should not exist in $\mathrm{Tl}(\mathrm{tpp})(\mathrm{OAc})-\mathrm{L}$ at $24^{\circ} \mathrm{C}$. This rules out the intermolecular ligand exchange mechanism.

If the carboxyl group is unidentate, one of the $\mathrm{C}-\mathrm{O}$ bonds should have enhanced the doublebond character and should give rise to a high-frequency band. Such bands are observed in the 1590 $1650 \mathrm{~cm}^{-1}$ region. ${ }^{8}$ However, the $v_{\text {asym }}(\mathrm{COO})$ band of $\mathrm{Tl}(\mathrm{tpp})(\mathrm{OAc})-\mathrm{L}$ observed at $1566 \mathrm{~cm}^{-1}$ (shown in Table 4) was inconsistent with unidentate coor- dination. Furthermore, according to Stoilova et al. ${ }^{9}$ unidentate acetates exhibit three bands (COO deformation) at $920-720 \mathrm{~cm}^{-1}$ and a strong band $\left[\pi\left(\mathrm{CO}_{2}\right)\right]$ at $540 \mathrm{~cm}^{-1}$. All these four bands are absent in $\mathrm{Tl}(\mathrm{tpp})(\mathrm{OAc})-\mathrm{L}$ at $24^{\circ} \mathrm{C}$. The two facts described above indicate that in $\mathrm{CH}_{2} \mathrm{Cl}_{2}$ at $24^{\circ} \mathrm{C}$ $\mathrm{Tl}(\mathrm{tpp})(\mathrm{OAc})$ should not be a monodentate acetate complex (structure I). Thus, the acetate coordination of $\mathrm{Tl}(\mathrm{tpp})(\mathrm{OAc})-\mathrm{L}$ at $24^{\circ} \mathrm{C}$ turns out to be asymmetric pseudo-chelating (III).

We propose the intramolecular acetato exchange mechanism (shown in Scheme II) to explain the observations of the IR and NMR measurements. The complex $\mathrm{Tl}(\mathrm{tpp})(\mathrm{OAc})-\mathrm{L}$ is chelating-bidentate (a) at low temperature (e.g. $-90^{\circ} \mathrm{C}$ ), which explains why the methyl and carbonyl carbons of the acetato group in $\mathrm{CD}_{2} \mathrm{Cl}_{2}$ are observed at 18.8 [with ${ }^{3} J\left(\mathrm{Tl}-{ }^{13} \mathrm{C}\right)=280 \mathrm{~Hz}$ ] and $174.9 \mathrm{ppm}$ [with ${ }^{2} J\left(\mathrm{Tl}-{ }^{13} \mathrm{C}\right)=235 \mathrm{~Hz}$, respectively. It also explains that the methyl proton signal is observed as a doublet at ca $0.06 \mathrm{ppm}$ [with ${ }^{4} J(\mathrm{~T}$ ]-H) $=14.7$ $\mathrm{Hz}$ ] at the same temperature. ${ }^{4}$ As the temperature increases from -90 to $24^{\circ} \mathrm{C}$, it becomes symmetrically pseudo-chelating $\mathbf{b}$, an intermediate of asymmetric pseudo-chelating $\mathrm{c}$ and $\mathbf{d}$. The $v_{\mathrm{as}}\left(\mathrm{CO}_{2}\right)$ band at $1566 \mathrm{~cm}^{-1}$ and $\delta\left(\mathrm{CH}_{3}\right)$ at $1391 \mathrm{~cm}^{-1}$ correspond to the structures $c$ and $d$. The rate of interchange between $\mathrm{c}$ and $\mathrm{d}$ is $\mathrm{ca} 10^{12}-10^{13} \mathrm{~s}^{-1}$. It is much faster than the NMR time-scale at $24^{\circ} \mathrm{C}$. On the NMR instrument only structure $b$ was detected at high temperature. This explains our previous report that the methyl protons of the apical acetate ligand were observed at $24^{\circ} \mathrm{C}$ as a sharp singlet at<smiles>C1O[AlH]1</smiles>

(II), a

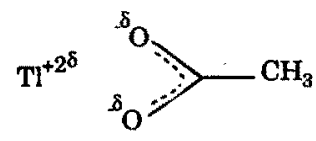

(IV) 

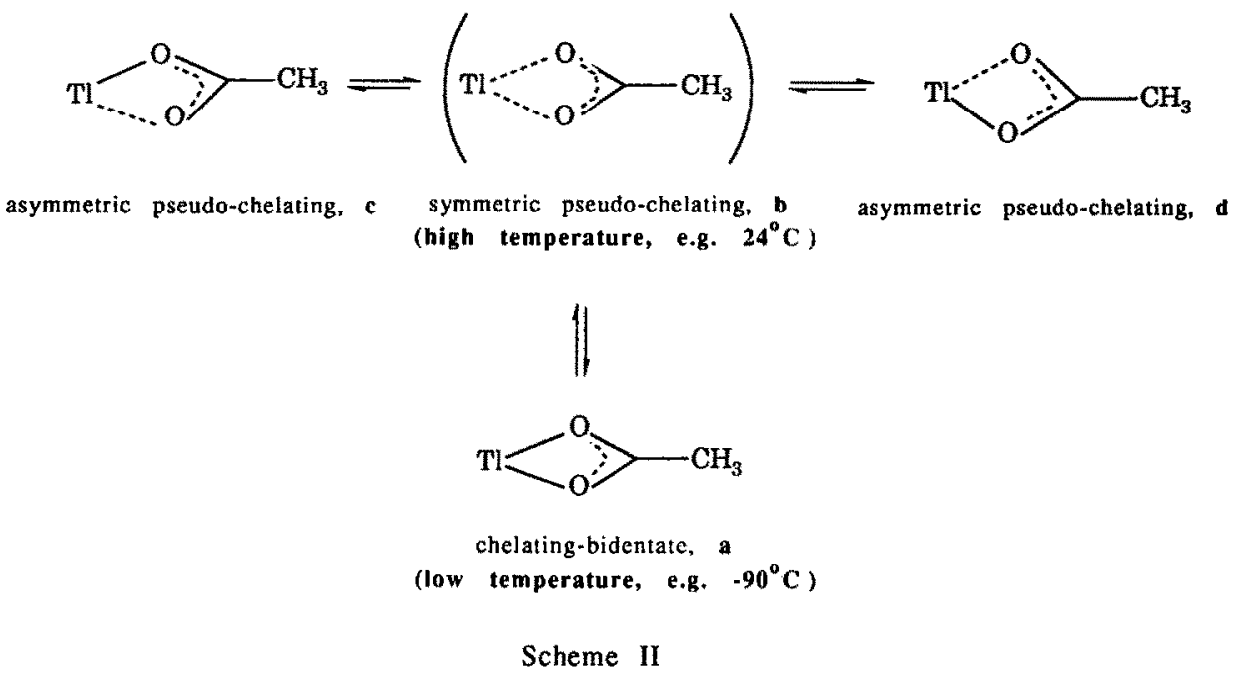

$\delta=0.06 \mathrm{ppm}$, with no evidence of coupling of the thallium nuclei with the acetate group. ${ }^{4}$ It also explains the disappearance of the symmetric modes of $\mathrm{COO}$, i.e. $v_{\mathrm{s}}\left(\mathrm{CO}_{2}\right)$ and $\delta(\mathrm{COC})$ and the enhancement of $v_{\text {as }}\left(\mathrm{CO}_{2}\right)$ for $\mathrm{Tl}(\mathrm{tpp})(\mathrm{OAc})-\mathrm{L}$ at high temperatures.

Acknowledgement - Financial support from the National Research Council of the R.O.C. under grant NSC-810208-M-005-13 is gratefully acknowledged.

\section{REFERENCES}

1. R. L. Rardin, W. B. Tolman and S. J. Lippard, New J. Chem. 1991, 15, 417.
2. G. B. Deacon and R. J. Phillips, Coord. Chem. Rev. 1980, 33, 227.

3. N. W. Alcock and V. M. Tracy, J. Chem. Soc., Dalton Trans. 1976, 2243.

4. J. C. Chen, H. S. Jang, J. H. Chen and L. P. Hwang, Polyhedron 1991, 10, 2069.

5. R. J. Abraham, G. E. Hawkes, M. F. Hudson and K. M. Smith, J. Chem. Soc., Perkin Trans II 1975, 204.

6. W. B. Lee, S. C. Suen, H. E. Hong, J. H. Chen, H. J. Lin, T. T. Jong and L. P. Hwang, submitted.

7. K. Ito and H. J. Bernstein, Can. J. Chem. 1956, 34, 170.

8. F. A. Cotton and G. Wilkinson, Advanced Inorganic Chemistry. John Wiley \& Sons, New York (1988).

9. D. Stoilova, G. Nikolov and K. Balarev, Izv. Akad. Nauk SSSR, Ser. Khim 1976, 9, 371. 